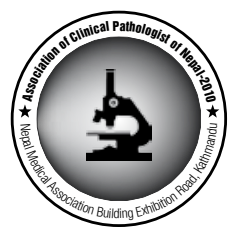

\title{
Myelodysplastic syndrome: classification and changing concept
}

\author{
Ghosh $\mathrm{A}^{1}$
}

${ }^{1}$ Department of Pathology, Manipal Teaching Hospital Manipal College of Medical Sciences, Pokhara, Nepal

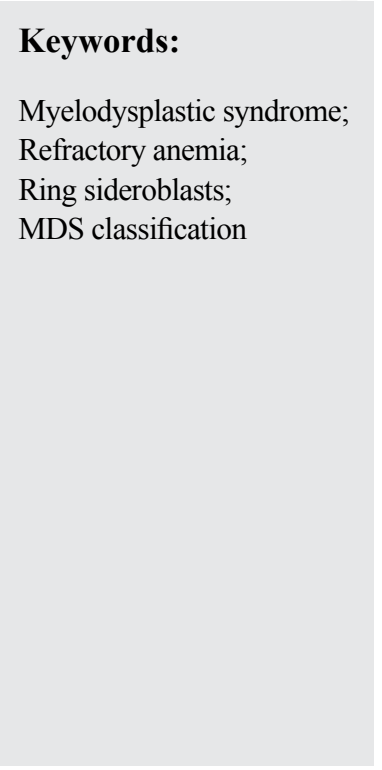

\begin{abstract}
Myelodysplastic syndrome is a group of clonal disorders having wide range of outcome. Its classification and concept have been changed over time with better understanding of its prognosis and clinical significance. The first standard classification was FAB classification which came in 1982. It was based on findings on peripheral blood and bone marrow. Later in 2001, WHO incorporated clinical data into it and proposed a modified classification. The 2001 WHO classification made several criteria and entities more precise based on inputs from several studies. New terminologies (e.g., refractory cytopenia with multilineage dysplasia) and new group (e.g., myelodysplastic / myeloproliferative disorder) have been introduced and group like 'refractory anemia with excess blasts in transformation' was removed. Again in 2008, in collaboration with European Association for Haematopathology and the Society for Hematopathology, as well as considering several recommendations from a group of clinical experts, WHO published a revised and updated classification. In the latest MDS classification, the clinical implications of different groups have been given more importance and also the role of cytogenetics has been re-evaluated. Several groups were again redefined (e.g., myelodysplastic syndrome - unclassified, refractory anemia with excess blasts) or eliminated (e.g., refractory cytopenia with multilineage dysplasia and ringed sideroblasts) or newly introduced (e.g., refractory cytopenia with unilineage dysplasia). Childhood MDS was considered separately as demanded by several pediatric hematologists. It was also emphasized that the diagnosis and classification of MDS mainly require identification of dysplastic morphological features, routine stains and correlation with clinical data rather than cytogenetics which may be necessary only in rare cases.
\end{abstract}

\section{INTRODUCTION}

The diagnosis and classification of myelodysplastic syndromes (MDS) always remained a challenge over past several decades. ${ }^{1}$ MDS can be defined as a group of several conditions characterized by clonal stem cell disorder that manifests dysplastic and ineffective blood cell production compounded by a variable risk of transformation to acute

\section{Correspondence:}

Dr. Ghosh A, MD

Department of Pathology, Manipal Teaching Hospital Manipal

College of Medical Sciences, Pokhara, Nepal

Email:drghosharnab@yahoo.com leukemia. ${ }^{2-5}$ The standard of care ranges from amelioration of hematologic deficits with blood product transfusions and administration of recombinant growth factors to aggressive chemotherapy and stem cell transplantation for younger individuals with more aggressive disease. ${ }^{6}$ Although generally it arises de novo with the risk increasing proportionate to age, MDS may also occur years after exposure to mutagenic chemotherapy. ${ }^{1,7}$ In this study we review the evolution of different classifications of MDS and the terminologies related to it over years.

In about one-third of patients, MDS can progress to a rapidly 
growing cancer of bone marrow cells called acute myeloid leukemia. Because most patients do not get leukemia, MDS was previously classified as a disease of low malignant potential. Now that we have learned more about MDS, it is considered to be a form of cancer as it is a clonal disease typical of cancer. ${ }^{8}$

\section{History}

In 1938, the term 'refractory anaemia'(RA) was used by Rhoades and Barker to describe anaemic patients who were unresponsive to iron, vitamin $\mathrm{B} 12$ or folic acid. ${ }^{5,9}$ A subgroup of patients with RA was subsequently shown to have ring sideroblasts in the bone marrow. ${ }^{9}$ Since then the classification and nomenclature used to describe this syndrome has changed over the last 70 years. Bjorkman ${ }^{10}$ in 1956 noticed cases of RA that were associated with ringed sideroblasts in the bone marrow (BM) and coined the term refractory anemia with ringed sideroblasts ( RARS ). In the 1950 s, it was appreciated that acute leukaemia in the elderly was often preceded by a 'pre-leukaemic' phase of peripheral blood cytopenia associated with either normal or a slightly increased percentage of bone marrow blasts. ${ }^{9}$ Later, in 1970s terminologies like preleukemic syndrome and Hematopoietic dysplasia and subacute myeloid leukemia came up. ${ }^{6}$ In 1982, the first standard classification was made as the French-American-British (FAB) group proposed a morphological classification based on the percentage of blasts and ringed sideroblasts in the bone marrow and the presence or absence of a peripheral blood monocytosis.

\section{Epidemiology}

MDS predominantly occurs in elderly with a median age of 70 years. ${ }^{1}$ The overall annual incidence rate is 3-4 per 100000 which increases dramatically to 20 per 100000 and 30 per 100000 in age group above 70 and 80 years. ${ }^{1,9}$ Males are affected approximately 1.5 times as often as females. ${ }^{11}$ Case control studies of possible occupational or environmental associations have provided many insights to MDS, but none other than benzene has reached a level of scientific validity. ${ }^{12,13}$

\section{Etiology}

The etiology of most cases of primary MDS remains unknown. ${ }^{9}$ MDS can occur as primary or de novo disorder and secondarily as therapy related disease (t-MDS). ${ }^{1}$ Primary or de novo MDS occurs without a known history of toxic exposure and in some studies, have been linked to exposure to benzene, solvents and pesticides, and with smoking. ${ }^{1,9}$ However it should be remembered that dysplasia in BM can be caused secondarily by several factors which should be excluded before a diagnosis of MDS is made. It is postulated that gene polymorphism may be linked to interaction to a particular environmental factor and increased susceptibility of an individual. The t-MDS occurs with a known history of chemotherapeutic agents, most commonly alkylating agents and radiotherapy. Rarely, inherited hematological conditions (e.g., Fanconi anemia ) are associated with MDS., ${ }^{1,6}$

\section{Clinical features}

Most patients present with symptoms or complication related to anemia or less commonly, neutropenia and thrombocytopenia. ${ }^{1}$ Upto $20 \%$ cases may be detected incidentally on routine laboratory tests. ${ }^{9}$ Lymphadenopathy and organomegaly are rare ${ }^{1,9}$ A diagnosis of MDS should be considered in any individual with unexplained persistent cytopenias or monocytosis. Diabetes insipidus, acute neutrophilic dermatosis and systemic supus erythematosus (SLE) like syndromes have been reported as presenting features. ${ }^{11}$

\section{Diagnosis}

A diagnosis of MDS should be considered in any individual with unexplained persistent cytopenias or monocytosis. The figure 1 shows the flow chart as a diagnostic approach in MDS. Careful inspection of the peripheral blood smear (PBS) and BM is necessary to document the requisite dysplastic cytologic features in one or more hematopoietic lineages. ${ }^{5,14}$ PBS and BM specimens should be collected prior to any definitive therapy. A standard Wright-Giemsa or similar stain is used for smears. BM biopsy ideally should be at least $1.5 \mathrm{~cm}$ in length and taken at right angles to the cortical bone. ${ }^{15}$ Confirmation of dysplasia, percentage of dysplastic cells and lineages affected and in selected cases percentage of ringed sideroblasts lead to subcategorization. However, because these dysplastic findings per se may not be diagnostic of MDS, possible contributing conditions e.g., nutritional status, alcohol and drug use, occupational exposure to petrochemicals and other toxins, prior treatment with antineoplastics or radiotherapy, growth factor therapy, and risk factors for human immunodeficiency virus (HIV) must be excluded. ${ }^{1,6,15}$ The preponderance of macrocytic anemia in MDS necessitates exclusion of vitamin B12 and folate deficiencies. A number of medications, including valproic acid, mycophenolate mofetil, ganciclovir, and alumtuzumab, have been associated with acquired dysplastic changes. ${ }^{6}$ In addition, copper deficiency and zinc excess may simulate myelodysplasia. ${ }^{6}$ Dysplastic hematopoiesis is a common finding that accompanies HIV infection. ${ }^{16,17,18}$ Other than these secondary causes of marrow dysplasia , diagnostic problems can arise when marrow hypocellularity or myelofibrosis obscures the underlying disease process or when BM morphologic findings do not match with PBS and laboratory findings or blast percentage is not increased in the PBS or BM. ${ }^{15,19.20}$

\section{Classifications of MDS}

Dysplasia is a term that classically implies a polyclonal and, therefore, nonneoplastic process. ${ }^{11}$ The choice of 


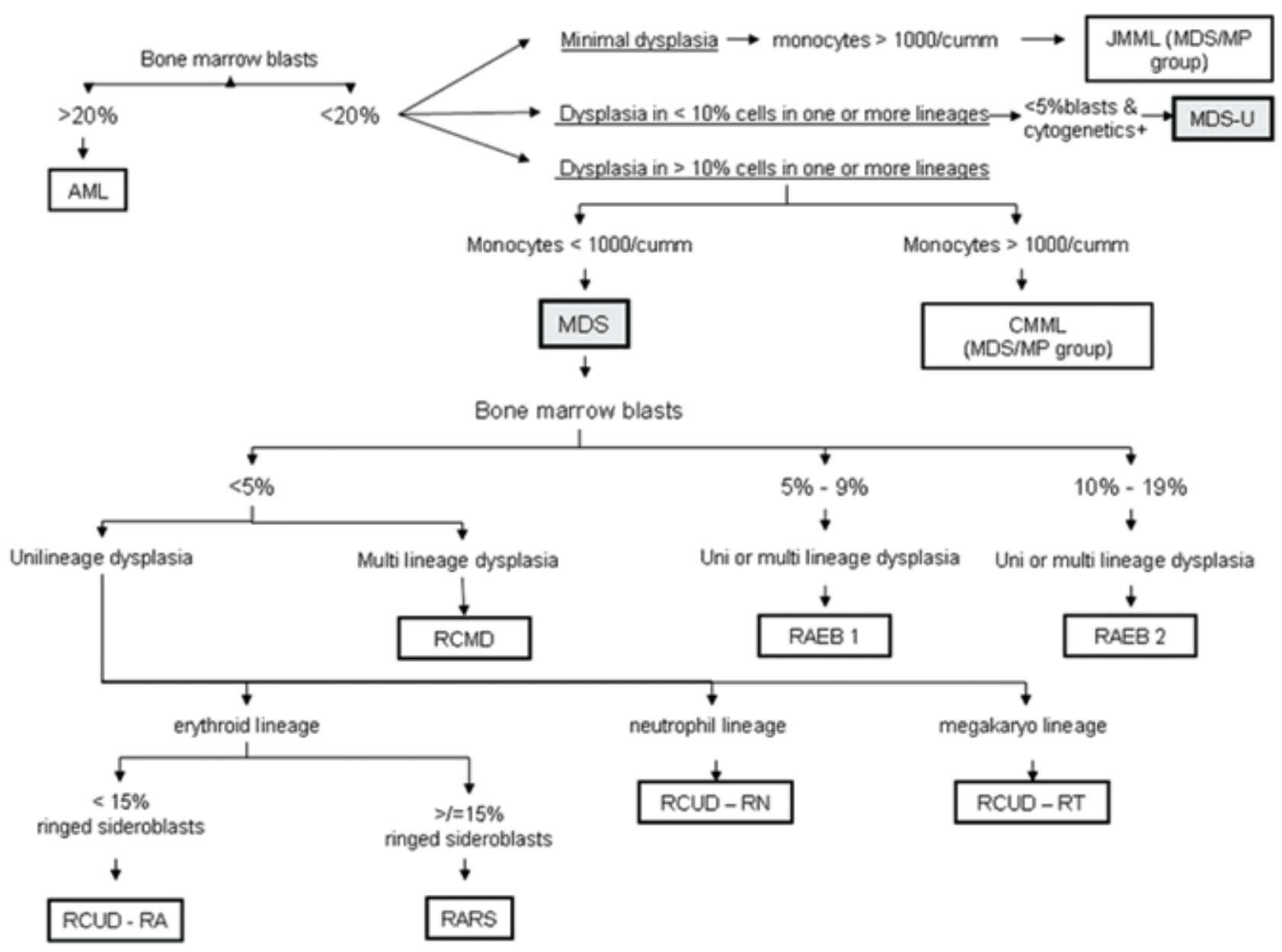

Figure 1: Flow chart showing schema of diagnostic approach in MDS

the term myelodysplasia to denote clonal (neoplastic) disorders was rather unfortunate because the term does not help in understanding the relationship of myelodysplasia to other clonal stem cell disorders. In addition, diseases such as idiopathic myelofibrosis can have all the features of "myelodysplasia" but are ignored in its classifications though it is widely used. ${ }^{11}$

\section{FAB classification}

Several classification systems have been developed to subclassify MDS and to predict survival or transition to AML following MDS diagnosis. The first standard classification, the FAB system, was introduced in 1982 and is based on the percentage of blasts and morphological dysplastic features of blood and BM. ${ }^{6,14}$ According to this system, patients are diagnosed with MDS when PBS and BM findings of unexplained hematopoietic dysplasia in two or more lineages are present and/or myeloblasts are less than $30 \%$ of all $\mathrm{BM}$ cells. ${ }^{14} \mathrm{FAB}$ classification distinguishes five morphologic subtypes of MDS namely RA, RARS, RAEB, RAEB-t and CMML (Table 1). ${ }^{6,14}$ However, the FAB system served as the standard for MDS classification for two decades for its easy reproducibility and provision of considerable prognostic information. ${ }^{6,21}$

Nonetheless, with time, the validity of the classification was questioned. ${ }^{6}$ Drawing diagnostic distinctions among different percentage of leukemic blast cells is inconsistent with the biologic behavior of the condition. ${ }^{11,22} \mathrm{RA}$ in FAB is a heterogenous group that includes patients with neutropenia and / or thrombocytopenia without anemia. ${ }^{9}$ In RARS , the percentage of ringed sideroblasts are more than $15 \%$. Separation of clonal RA into two categories based on whether the anemia has greater than or less than 15 percent sideroblasts is arbitrary and is not based on the pathobiology of the two variants. ${ }^{11}$ This criteria , however was taken somewhat arbitrarily. The blasts percentage in RAEB was between 5 and 19\% while in RAEB-t, it is between $20 \%$ and $29 \%$. In general, RAEB patients have more unfavorable prognosis than RARS and RAEB-t patients follows a more indolent course than AML. ${ }^{9,23}$ CMML in FAB classification encompasses all cases with marrow dysplasia and more than 1000 / cumm circulating monocytes. It was recognized to be heterogeneous as it includes patients with a high monocyte count and splenomegaly more typical of a myeloproliferative (MP) disorder as well as patients with a modest monocytosis 
Table 1: The FAB classification of MDS 1982. ${ }^{6,9,14}$

\begin{tabular}{c|c|c|c|c|c}
\hline \multirow{2}{*}{ Classification } & \multicolumn{2}{|c|}{ Peripheral Blood } & \multicolumn{3}{c}{ Bone Marrow } \\
\cline { 2 - 6 } & Blast Cells (\%) & $\begin{array}{c}\text { Monocytes } \\
\mathbf{1 0 0 0 / \mathbf { c u m m }}\end{array}$ & Blast Cells (\%) & $\begin{array}{c}\text { Ringed Sideroblasts } \\
\mathbf{( \% )}\end{array}$ & Dysplasia \\
\hline $\begin{array}{c}\text { Refractory anaemia (RA) } \\
\begin{array}{c}\text { Refractory anaemia with ringed } \\
\text { sideroblasts (RARS) }\end{array}\end{array}$ & $<1$ & No & $<5$ & $<15$ & Yes \\
$\begin{array}{c}\text { Refractory anaemia with excess } \\
\text { blasts (RAEB) }\end{array}$ & $<5$ & No & $<5$ & Variable & Yes \\
$\begin{array}{c}\text { Refractory anaemia with excess } \\
\text { blasts in transformation (RAEB-t) }\end{array}$ & $<5$ & No & $5-19$ & Variable & Yes \\
\hline $\begin{array}{c}\text { Chronic myelomonocytic leukemia } \\
\text { (CMML) }\end{array}$ & $<5$ & $+/-$ & $20-29$ & Variable & Yes \\
\hline
\end{tabular}

Table 2: WHO classification of MDS $20011^{1}$

\begin{tabular}{|c|c|c|}
\hline Classification & Peripheral Blood & Bone Marrow \\
\hline $\begin{array}{l}\text { Refractory anemia } \\
\text { (RA) }\end{array}$ & $\begin{array}{l}\text { Anemia } \\
\text { No or rare blasts }\end{array}$ & $\begin{array}{l}\text { Erythroid dysplasia only } \\
<5 \% \text { blasts } \\
<15 \% \text { ringed sideroblasts }\end{array}$ \\
\hline $\begin{array}{l}\text { Refractory anemia with ringed } \\
\text { sideroblasts (RARS) }\end{array}$ & $\begin{array}{l}\text { Anemia } \\
\text { No blasts }\end{array}$ & $\begin{array}{l}>15 \% \text { ringed sideroblasts } \\
<5 \% \text { blasts } \\
\text { Erythroid dysplasia only }\end{array}$ \\
\hline $\begin{array}{l}\text { Refractory cytopenia with multi- } \\
\text { lineage dysplasia } \\
\text { (RCMD) }\end{array}$ & $\begin{array}{l}\text { Cytopenias (bicytopenia or pancy- } \\
\text { topenia) } \\
\text { No or rare blasts } \\
\text { No Auer rods } \\
<1 \times 109 / \text { L monocytes }\end{array}$ & $\begin{array}{l}\text { Dysplasia in } \geq 10 \% \text { of the cells of two or more myeloid } \\
\text { cell lines } \\
<5 \% \text { blasts in the marrow } \\
\text { No Auer rods } \\
<15 \% \text { ringed sideroblasts }\end{array}$ \\
\hline $\begin{array}{l}\text { Refractory cytopenia with multi- } \\
\text { lineage dysplasia and ringed } \\
\text { sideroblasts } \\
\text { (RCMD-RS) }\end{array}$ & $\begin{array}{l}\text { Cytopenias (bicytopenia or pancy- } \\
\text { topenia) } \\
\text { No or rare blasts } \\
\text { No Auer rods } \\
<1 \times 109 / \text { L monocytes }\end{array}$ & $\begin{array}{l}\text { Dysplasia in } \geq 10 \% \text { of the cells of two or more myeloid } \\
\text { cell lines } \\
<5 \% \text { blasts in the marrow } \\
>15 \% \text { ringed sideroblasts } \\
\text { No Auer rods }\end{array}$ \\
\hline $\begin{array}{l}\text { Refractory anemia with excess } \\
\text { blasts-1 } \\
\text { (RAEB-1) }\end{array}$ & $\begin{array}{l}\text { Cytopenias } \\
<5 \% \text { blasts } \\
\text { No Auer rods } \\
<1 \times 109 / \text { L monocytes }\end{array}$ & $\begin{array}{l}\text { Unilineage or multilineage dysplasia } \\
5-9 \% \text { blasts } \\
\text { No Auer rods }\end{array}$ \\
\hline $\begin{array}{l}\text { Refractory anemia with excess } \\
\text { blasts-2 } \\
\text { (RAEB-2) }\end{array}$ & $\begin{array}{l}\text { Cytopenias } \\
5-19 \% \text { blasts } \\
\text { Auer rods } \pm \\
<1 \times 109 / \text { L monocytes }\end{array}$ & $\begin{array}{l}\text { Unilineage or multilineage dysplasia } \\
10-19 \% \text { blasts } \\
\text { Auer rods } \pm\end{array}$ \\
\hline $\begin{array}{l}\text { Myelodysplastic syndrome, } \\
\text { unclassified } \\
\text { (MDS-U) }\end{array}$ & $\begin{array}{l}\text { Cytopenias } \\
\text { No or rare blasts } \\
\text { No Auer rods }\end{array}$ & $\begin{array}{l}\text { Unilineage dysplasia: one myeloid cell line } \\
<5 \% \text { blasts } \\
\text { No Auer rods }\end{array}$ \\
\hline $\begin{array}{l}\text { MDS associated with isolated } \\
\text { del }(5 q)\end{array}$ & $\begin{array}{l}\text { Anemia } \\
\text { Usually normal or increased } \\
\text { platelet count } \\
<5 \% \text { blasts }\end{array}$ & $\begin{array}{l}\text { Normal to increased megakaryocytes with hypolobated } \\
\text { nuclei } \\
<5 \% \text { blasts } \\
\text { Isolated del( } 5 q) \text { cytogenetic abnormality } \\
\text { No Auer rods }\end{array}$ \\
\hline
\end{tabular}

and a clinical course similar to that seen in RA or RAEB. ${ }^{9}$ Nonetheless, in different studies over time, it was revealed that the clinical outcomes of patients assigned to the same MDS subgroup in FAB remained too variable to accurately predict survival or transformation to AML in individual patients. ${ }^{21}$

\section{WHO classification 2001}

In 2001, the WHO proposed a revision of the FAB morphological approach and incorporated more recent clinical and genetic data. ${ }^{9,21}$ Table 2 shows the subcategories and their respective diagnostic criteria and Table 3 shows a 
comparison between FAB and WHO 2001 classifications. The WHO classification recognizes the prognostic importance of the percentage of BM blasts in MDS and includes myeloblasts, monoblasts, promonocytes and megakaryoblasts, but not erythroblasts. ${ }^{1,15}$

\section{Removed from MDS}

The revisions included lowering the threshold for the percentage of blasts for the diagnosis of AML from 30\% to $20 \%$, thus elimination of the MDS subcategory RAEB-t. All cases with more than $20 \%$ blasts and dysplasia in more than $50 \%$ of cells in at least 2 lines have been classified as AML with multilineage dysplasia, and it may occur either de novo or following MDS or a myelodysplastic / myeloproliferative disorder (MDS/MP). ${ }^{1}$ In addition, CMML was reclassified from the subcategory of MDS to a new subcategory of MDS/MP.

\section{New terms}

It was noted that patients with less than 5\% marrow blasts had a poorer prognosis if they had multilineage dysplasia. In WHO 2001 classification, RA and RARS are confined to patients with unilineage erythroid dysplasia and new terms, RCMD and RCMD-RS have been introduced for cases with bi- or pancytopenia and dysplastic features in more than $10 \%$ of cells in two or more myeloid lineages (Table 2, Table 3). ${ }^{1,69}$

RAEB has been divided into 2 subcategories viz RAEB-1 and RAEB-2 based on the observation that higher number blasts in PBS or BM denoted poorer prognoses. ${ }^{1}$ Moreover though the significance of Auer rods within blast cells remained uncertain in classifying MDS, but any patients in whom Auer rods are seen are categorized as having RAEB$2 .{ }^{9}$

A new subgroup of MDS unclassified (MDS-U) has also been introduced specifically for patients with unilineage, myeloid or megakaryocytic dysplasia and not as a waste basket group for inadequately investigated cases.

Similarly, another new subgroup has been introduced i.e; MDS with isolated 5q deletion, based on the uniformity of clinical and laboratory features of cases. ${ }^{1}$ Majority of these patients were elderly women with a macrocytic anaemia, normal white cell count and a normal or raised platelet count. ${ }^{1,9}$ BM of these patients show erythroid hypoplasia and large mono- or binuclear megakaryocytes. ${ }^{9}$

\section{Progression to other group}

It was also described that though some patients may remain within a single WHO subgroup, others may progress through two or more subgroups during the course of their disease. ${ }^{1,9}$

\section{Recommendation for follow up}

Patients with unilineage erythroid dysplasia, or in whom dysplasia is seen in $<10 \%$ of cells are not diagnosed as "MDS" in the absence of a clonal karyotypic abnormality. It is recommended that such patients be re-evaluated after 6 months. ${ }^{1,9}$

\section{WHO classification 2008}

In 2008, WHO in collaboration with the European Association for Haematopathology and the Society for Hematopathology, published a revised and updated edition of the WHO Classification of Tumors of the Hematopoietic and Lymphoid Tissues. While developing the classification system, a Clinical Advisory Committee of 30 renowned clinical experts of relevant fields met with Pathology Committee and made several recommendations. ${ }^{15,21}$ It was decided that the definition of subgroups of MDS should be more clearly redefined with precise clinical relevance and also the diagnostic role of cytogenetics and flow cytometry be clarified and re-evaluated. ${ }^{15,21}$

The basic minimal criteria for diagnosis of MDS remains same i.e., at least $10 \%$ cells in one or more cell line must show unequivocal dysplastic features. It is again reemphasized that before a diagnosis of MDS is made, all secondary causes and congenital abnormalities should be excluded. ${ }^{8,15}$

Table 4 shows the WHO classification 2008 while in Tables 5 and 6 we have summarized the basic approach in diagnosis based on PBS and BM findings. Table 7 shows the older terminologies of FAB and WHO 2001 and their current counterparts.

\section{New group}

The group MDS-U of WHO2001 has been re-evaluated. Refractory cytopenia with unilineage dysplasia (RCUD) has been expanded to include any unilineage dysplasia with less than $5 \%$ blasts in marrow irrespective of uni or bi-cytopenia in PBS. ${ }^{8,15,24,25}$ Thus new entities RCUD-RN and RCUD-RT have evolved. On the other hand, patients with pancytopenia and unilineage morphologic dysplasia are classified as having MDS- $\mathrm{U}$, because of the uncertain clinical significance of such findings.

\section{New definition}

The definition of RAEB-1 and -2 have been redefined to emphasize blasts percentage in PBS. ${ }^{15,24,25}$ RAEB-1 includes patients with $2-4 \%$ blasts in PB even if BM blasts is $<5 \%$. RAEB-2 includes patients with 5-19\% blasts in PBS or 10$19 \%$ blasts in BM. So, cases of RAEB-2 may have $<10 \%$ blasts in the marrow but may be diagnosed by other 2 findings; $5 \%$ to $19 \%$ blasts in the blood and/or Auer rod. ${ }^{15,24,25}$ 
Table 3: Relationship between the FAB and WHO classification 20019

\begin{tabular}{|c|c|}
\hline FAB & WHO 2001 \\
\hline RA & $\begin{array}{l}\text { RA (unilineage) } \\
\text { RCMD } \\
5 q-\text { syndrome }\end{array}$ \\
\hline RARS & $\begin{array}{l}\text { RARS (unilineage) } \\
\text { RCMD-RS }\end{array}$ \\
\hline RAEB & $\begin{array}{l}\text { RAEB-1 } \\
\text { RAEB-2 }\end{array}$ \\
\hline RAEBt & $\begin{array}{l}\text { AML with multilineage dysplasia } \\
\text { AML and MDS, therapy related }\end{array}$ \\
\hline CMML & Myelodysplastic/myeloproliferative diseases \\
\hline-- & $\begin{array}{l}\text { New Terminology - } \\
\text { RCMD , RCMD-RS , RAEB1, RAEB2, } \\
\text { MDS-U, 5q- syndrome } \\
\text { New Group - } \\
\text { MDS/MP }\end{array}$ \\
\hline
\end{tabular}

Table 5: Peripheral blood approach in diagnosis of MDS

\begin{tabular}{|c|c|c|}
\hline \multicolumn{2}{|c|}{ Peripheral blood findings } & \multirow{2}{*}{$\begin{array}{l}\text { Possible diagnosis ( under MDS ) } \\
\text { RCUD - RA/RN / RT } \\
\text { RARS } \\
\text { RCMD } \\
\text { MDS - U } \\
5 q-\text { ( platelet normal / increased ) }\end{array}$} \\
\hline \multirow{3}{*}{$\begin{array}{c}\text { Cytopenia(s) } \\
<1000 / \text { cumm } \\
\text { monocytes }\end{array}$} & $\begin{array}{l}\text { No or rare } \\
\text { blasts }(<1 \%) \\
\text { No Auer } \\
\text { rods }\end{array}$ & \\
\hline & $\begin{array}{l}<1000 / \\
\text { cumm } \\
\text { monocytes }\end{array}$ & RAEB- 1 \\
\hline & $\begin{array}{l}5 \%-19 \% \\
\text { blasts } \\
\text { Auer rods } \\
+/-\end{array}$ & RAEB- 2 \\
\hline $\begin{array}{l}>1000 \\
/ \text { cumm } \\
\text { monocytes }\end{array}$ & $<20 \%$ blasts & $\begin{array}{l}\text { CMML ( chronic myelomonocytic } \\
\text { leukemia ) } \\
\text { JMML ( Juvenile myelomonocytic } \\
\text { leukemia ) } \\
\text { ( both come under MDS/MPD } \\
\text { group ) }\end{array}$ \\
\hline
\end{tabular}

Table 4: WHO classification of MDS $2008^{15}$

\begin{tabular}{|c|c|c|}
\hline Disease & Blood findings & BM findings \\
\hline $\begin{array}{l}\text { Refractory cytopenia with unilin- } \\
\text { eage dysplasia (RCUD): } \\
\text {-Refractory anemia -RA } \\
\text {-Refractory neutropenia -RN } \\
\text {-Refractory thrombocytopenia - RT }\end{array}$ & $\begin{array}{l}\text { Unicytopenia or bicytopenia } \\
\text { No or rare blasts }(<1 \%)\end{array}$ & $\begin{array}{l}\text { Unilineage dysplasia }>10 \% \text { of the cells in one myeloid } \\
\text { lineage } \\
<5 \% \text { blasts } \\
<15 \% \text { of erythroid precursors are ring sideroblasts }\end{array}$ \\
\hline $\begin{array}{l}\text { Refractory anemia with ring sid- } \\
\text { eroblasts (RARS) }\end{array}$ & $\begin{array}{l}\text { Anemia } \\
\text { No blasts }\end{array}$ & $\begin{array}{l}\text { Erythroid dysplasia only } \\
<5 \% \text { blasts } \\
\geq 15 \% \text { of erythroid precursors are ring sideroblasts }\end{array}$ \\
\hline $\begin{array}{l}\text { Refractory cytopenia with multilin- } \\
\text { eage dysplasia (RCMD) }\end{array}$ & $\begin{array}{l}\text { Cytopenia(s) } \\
\text { No or rare blasts }(<1 \%) \\
\text { No Auer rods } \\
<1000 / \text { cumm monocytes }\end{array}$ & $\begin{array}{l}\text { Dysplasia in }>10 \% \text { of the cells in } \geq 2 \text { myeloid lineages } \\
\text { (neutrophil and/or erythroid precursors and/or mega- } \\
\text { karyocytes) } \\
<5 \% \text { blasts in marrow } \\
\text { No Auer rods } \\
+/-15 \% \text { ring sideroblasts }\end{array}$ \\
\hline $\begin{array}{l}\text { Refractory anemia with excess } \\
\text { blasts-1 (RAEB-1) }\end{array}$ & $\begin{array}{l}\text { Cytopenia(s) } \\
<5 \% \text { blasts } \\
\text { No Auer rods } \\
<1000 / \text { cumm monocytes }\end{array}$ & $\begin{array}{l}\text { Unilineage or multilineage dysplasia } \\
5 \%-9 \% \text { blasts } \\
\text { No Auer rods }\end{array}$ \\
\hline $\begin{array}{l}\text { Refractory anemia with excess } \\
\text { blasts-2 (RAEB-2) }\end{array}$ & $\begin{array}{l}\text { Cytopenia(s) } \\
5 \%-19 \% \text { blasts } \\
\text { Auer rods }+/- \\
<1000 / \text { cumm monocytes }\end{array}$ & $\begin{array}{l}\text { Unilineage or multilineage dysplasia } \\
10 \%-19 \% \text { blasts } \\
\text { Auer rods }+/-\end{array}$ \\
\hline $\begin{array}{l}\text { Myelodysplastic syndrome-- } \\
\text { unclassified } \\
\text { (MDS-U) }\end{array}$ & $\begin{array}{l}\text { Cytopenias } \\
<1 \% \text { blasts }\end{array}$ & $\begin{array}{l}\text { Unequivocal dysplasia in }<10 \% \text { of cells in one or more } \\
\text { myeloid lineages when accompanied by a cytogenetic } \\
\text { abnormality considered as presumptive evidence for a } \\
\text { diagnosis of MDS } \\
<5 \% \text { blasts }\end{array}$ \\
\hline $\begin{array}{l}\text { MDS associated with isolated } \\
\operatorname{del}(5 q)\end{array}$ & $\begin{array}{l}\text { Anemia } \\
\text { Usually normal or increased } \\
\text { platelet count } \\
\text { No or rare blasts }(<1 \%)\end{array}$ & $\begin{array}{l}\text { Normal to increased megakaryocytes with hypolobated } \\
\text { nuclei } \\
<5 \% \text { blasts } \\
\text { Isolated del }(5 q) \text { cytogenetic abnormality } \\
\text { No Auer rods }\end{array}$ \\
\hline
\end{tabular}


Table 6: Bone marrow approach in diagnosis of MDS

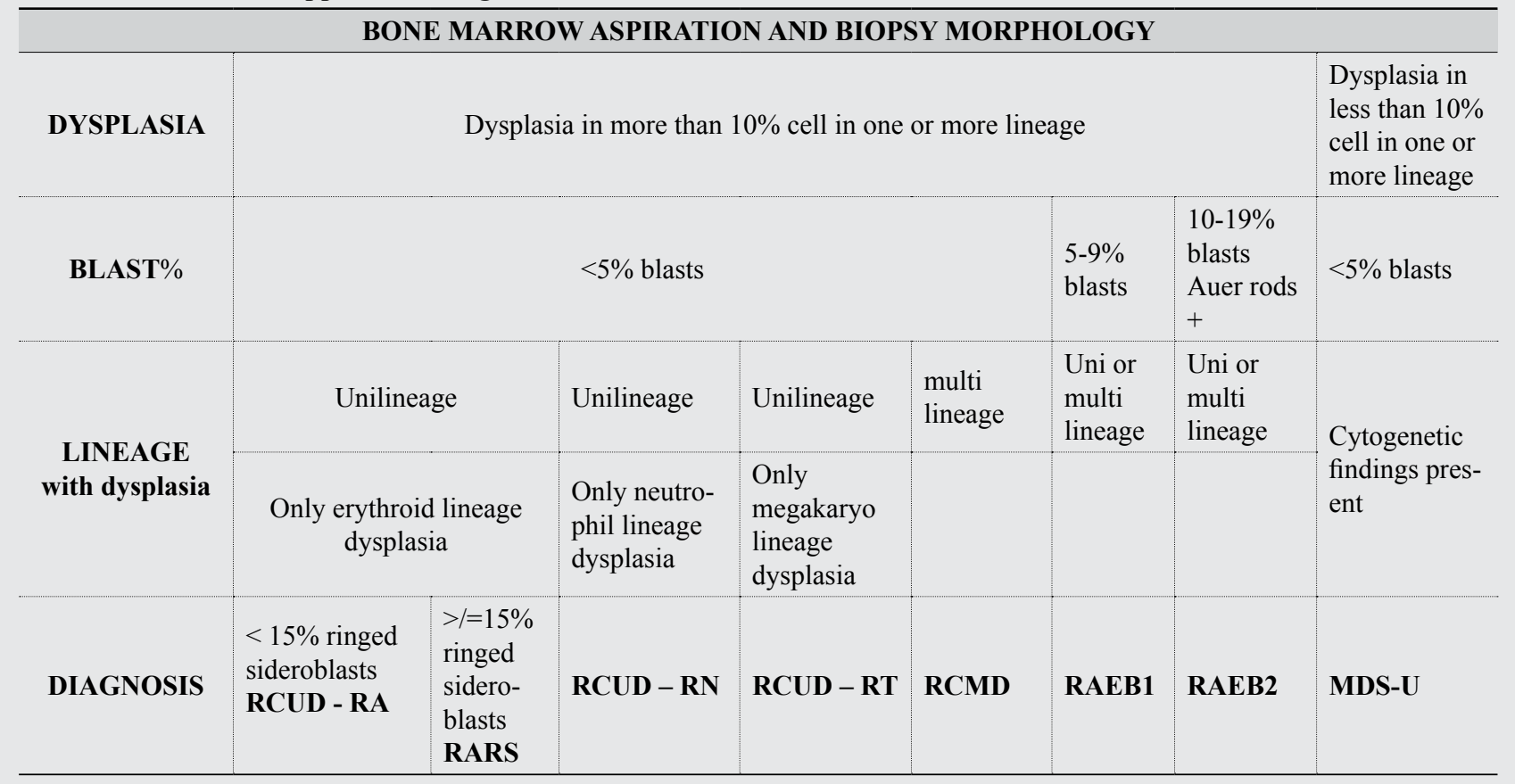

\section{Elimination of group}

A separate group RCMD-RS of WHO2001 classification has been eliminated in 2008 classification and is incorporated under RCMD. . $^{15,24,25}$

\section{Cytogenetics}

Fifty percent of patients with a primary myelodysplastic syndrome have a normal karyotype; hence, the current classification system is still largely based on morphology. ${ }^{26}$

Nonetheless, in WHO2008, a list of specific chromosomal abnormalities has been published. It was decided that Patients with refractory cytopenia(s) suspected to have MDS, but who lack diagnostic morphologic features may be considered to have presumptive evidence of MDS if they have specific MDS related cytogenetic abnormalities. Patients with pancytopenia and less than $10 \%$ dysplasia can be categorized under MDS-U if they show specific cytogenic abnormalities. It might also be of significance in unusual presentations like hypocellular or fibrotic marrow. Very recently, in 2011 , Bejar R et al found that somatic point mutations are common in myelodysplastic syndromes and are associated with specific clinical features and prognosis. ${ }^{26,27}$

\section{Flow cytometry and phenotypic abnormality}

Though there are several studies demonstrating phenotypic abnormalities inflow cytometry in MDS cases, it has not been considered as "definite" diagnostic evidence due to inadequate data. ${ }^{15,24,25}$ In absence of morphological and/ or cytological features, if a case has 3 or more phenotypic abnormality in flow cytometry, it can be reported as "suggestive of MDS" ( rather than "MDS") and should be followed up. ${ }^{15,24,25}$

\section{MDS with unusual presentation}

It was noted that some cases of MDS present with hypocellular marrow or myelofibrosis. ${ }^{15,24}$ It was further commented that hypocellular cases may show macrocytes in PB mimicking aplastic anemia and myelofibrosis cases may mimic AML-M7 and Idiopathic myelofibrosis (under myeloproliferative diseases). However; the clinical significance of these types of MDS are yet to be defined and so they are not categorized under any separate group. It was suggested that these cases should be subtyped as per MDS criteria with "hypoplastic" or "myelofibrosis" as prefix or suffix (e.g., RCMD with myelofibrosis). In cases with difficulty, immunohistochemical stains and cytogenetics would be helpful. ${ }^{19,28,29}$ Usually mylofibrosis cases show increased CD34+ blasts and hypoplastic cases are of lower grade. ${ }^{15,24}$

\section{Follow up recommended}

The following conditions are not classified as MDS and careful follow up is advised to monitor development of any features of MDS. ${ }^{15}$

a. Patients with refractory cytopenia but lacking morphologic or specific cytogenic abnormality 
b. "Suggestive of MDS" cases, i.e., with 3 or more phenotypical abnormalities only

c. Unilineage dysplasia present in BM but no increase in blasts and ringed sideroblasts are $<15 \%$ and no cytogenic abnormality

\section{Childhood MDS}

In WHO 2008 classification, childhood MDS was considered separately as demanded by several pediatric hematologists. ${ }^{15,24,25}$ A provisional entity, "refractory cytopenia of childhood" (RCC), has been added to include children with cytopenia(s) with less than $2 \%$ blasts in the peripheral blood and less than $5 \%$ in the bone marrow and evidence of dysplasia in 2 or more lineages (Table 8). ${ }^{15}$ They usually present with refractory anemia, initially associated with thrombocytopenia and/or neutropenia and hypocellular BM. ${ }^{15,24,25,30}$ Sometimes, the distinction between RCC and aplastic anemia or congenital bone marrow failure syndromes may be very difficult on morphological ground and cytogenetic abnormalities may be needed.For children with $2 \%$ to $19 \%$ blasts in the blood and/or $5 \%$ to $19 \%$ in the bone marrow, the MDS subclassification should be made using the same criteria used for adults. ${ }^{15}$

\section{RARS-T}

"Refractory anemia with ring sideroblasts and thrombocytosis" (RARS-T) does not come under MDS. (Please note that T stands for "thrombocytosis" and not "in transformation" like RAEB-t) It is a "provisional entity" kept under MDS/MP group with CMML and JMML. It includes cases with refractory anemia, thrombocytosis > 450000/cumm in PB and BM showing dyserythropoiesis, ringed sideroblasts $>15 \%$ and megakaryocytes with features resembling those in primary myelofibrosis or essential thromocythemia. ${ }^{15}$

\section{CONCLUSION}

No clinical features are specifically associated with MDS to differentiate it from other pancytopenic states. In $50 \%$ of patients, diagnosis depends on the process of elimination. Observation time and repeated BM studies may be necessary. It is to re-emphasize that diagnosis and classification of MDS mainly requires identification of dysplastic morphological features, routine stains and correlation with clinical data. Cytogenetics are necessary only in cases with inadequate morphological evidence which are rare. However very recently some studies show prognostic implications of point mutations

\section{ACKNOWLEDGMENT}

The author is very grateful to Prof. OP Talwar, Dr. D Ghartimagar, N Nepal and R Narasimhan for their tremendous help.

Table 7: Comparison between older nomenclatures (FAB and WHO 2001) and WHO classification 2008

\begin{tabular}{ll}
\hline $\begin{array}{l}\text { Older nomenclatures } \\
\text { ( FAB and WHO 2001) }\end{array}$ & Current nomenclatures \\
\hline RA (FAB, WHO 2001) & $\begin{array}{l}\text { RCUD - RA, new entity } \\
\text { ( In RCUD other entities are RN and RT ) }\end{array}$ \\
\hline RARS (FAB, WHO 2001) & $\begin{array}{l}\text { In RARS - a new provisional entity is RARS -thrombocytosis (RARS-t), which is } \\
\text { under MDS / MPD and usually has a JAK2 mutation }\end{array}$ \\
\hline RCMD -RS (WHO 2001) & A separate RCMD - RS has been removed and has been included under RCMD \\
\hline RAEB (FAB) & Divided into RAEB-1 and RAEB-2 \\
\hline RAEB - t (FAB) & Eliminated, comes under Acute leukemia \\
\hline CMML (FAB) & Removed from MDS and put under MDS/MP \\
\hline MDS-U (WHO 2001) & Several cases have been included in RCUD-RN and RCUD-RT \\
& $\begin{array}{l}\text { New terminologies } \\
\text { a)RCUD-RA, RCUD-RN, RCUD-RT } \\
\text { b)Refractory cytopenia of childhood ( RCC) } \\
\text { c)RARS-t ( under MDS/MP group) }\end{array}$ \\
\hline
\end{tabular}

Table 8: Marrow dysplasia in children ${ }^{15,24,25}$

\begin{tabular}{lll}
\hline Peripheral blood & Bone marrow & Diagnosis \\
\hline$<2 \%$ blasts & $<5 \%$ blasts & Refractory cytopenia of childhood RCC \\
$2-19 \%$ blasts & $5-19 \%$ blasts & Classify as MDS with criteria for adults \\
\hline
\end{tabular}




\section{REFERENCES}

1. Brunning RD, Head D, Bennett JM. Myelodysplastic syndromes. In : Jaffe ES, Harris NL, Stein H, Vardiman JW, editors. World Health Organization Classification of Tumours - Pathology and Genetics of Tumours of Haematopoietic and Lymphoid Tissues. IARC Lyon, France; 2001.

2. Greenberg PL. The smoldering myeloid leukemic states: Clinical and biologic features. Blood 1983;61:1035-44.

3. Koeffler HP, Golde DW. Human preleukemia. Ann Intern Med 1980;93:347-53.

4. Noel P, Solberg LA Jr. Myelodysplastic syndromes. Pathogenesis, diagnosis and treatment. Crit Rev Oncol Hematol 1992;12:193-215.

5. Doll DC, List AF. Myelodysplastic syndromes. West J Med 1989;151:161-7.

6. List AF, Sandberg AA, Doll DC. Myelodysplastic syndrome. In: Greer JP, Foerster J, Rodgers GM, Paraskeva F, Glader B,Arbor DA,Means RT, Greer JP Jr. editors. Wintrobes' clinical hematology. 12th ed. Lippincott Williams Wilkins: Philadelphia; 2009.pp1957.

7. Levine EG, Bloomfield CD. Leukemias and myelodysplastic syndromes secondary to drug, radiation, and environmental exposure. Semin Oncol 1992;19:47-84.

8. Myelodysplastic syndromes, American Cancer Society, published on 26 Apr 2010. [31 screens] Available in URL: http://www.cancer. org/acs/groups/cid/documents/webcontent/003122-pdf.pdf

9. David GO, Sally BK. Myelodysplastic syndromes Chap 40.In: Hoffbrand AV,Catovsky D, Tuddenham EGD. Editors. Postgraduate Haematology. 5th ed. Blackwell. 2005. pp662-80.

10. Bjorkman SE. Chronic refractory anemia with sideroblastic bone marrow; a study of four cases. Blood 1956;11:250-9.

11. Myelodysplastic Syndromes (Clonal Cytopenias and Oligoblastic Leukemia): Overview. In:Lichtman M, Beutler E, Kaushansky K, Kipps T, Seligsohn U, Prchal J. editors. Williams Hematology. 7th ed McGraw Hill New York, 2007.

12. West RR, Stafford DA, White DT et al: Cytogenetic abnormalities in the myelodysplastic syndromes and occupational or environmental exposure. Blood 2000;95:2093-7.

13. Nisse C, Haguenoer JM, Grandbastien B. Occupational and environmental risk factors of the myelodysplastic syndromes in the North of France. Br J Haematol 2001;112:927-35.

14. Bennett JM, Catovsky D, Daniel MT, Flandrin G, Galton DA, Gralnick $\mathrm{HR}$, et al. Proposals for the classification of the myelodysplastic syndromes. Br J Haematol 1982;51: 189-99.

15. Vardiman JW, Thiele J, Arber DA et al. The 2008 revision of the WHO classification of myeloid neoplasms and acute leukemia: rationale and important changes.Blood. 2009;114:937-51.

16. Spivak JL, Selonick SE, Quinn TC. Acquired immune deficiency syndrome and pancytopenia. JAMA 1983;250:3084-7.
17. Schneider DR, Picker LJ. Myelodysplasia in the acquired immune deficiency syndrome. Am J Clin Pathol 1985;84:144-52.

18. Karcher DS, Frost AR. The bone marrow in human immunodeficiency virus (HIV)-related disease. Morphology and clinical correlation. Am J Clin Pathol 1991;95:63-71.

19. Orazi A, Albitar M, Heerema NA, Haskins S, Neiman RS. Hypoplastic myelodysplastic syndromes can be distinguished from acquired aplastic anemia by CD34 and PCNA immunostaining of bone marrow biopsy specimens. Am J Clin Pathol 1997;107:268-74.

20. Vardiman JW. Hematopathological concepts and controversies in the diagnosis and classification of myelodysplastic syndromes. Hematology Am Soc Hematol Educ Program. 2006;199-204.

21. Mufti GJ, Bennett JM, Goasguen J, Bain BJ, Baumann I, Brunning $\mathrm{R}$, et al . Diagnosis and classification of myelodysplastic syndrome: International Working Group on Morphology of myelodysplastic syndrome (IWGM-MDS) consensus proposals for the definition and enumeration of myeloblasts and ring sideroblasts. Haematologica 2008;93:1712-7.

22. Lichtman MA. Myelodysplasia or myeloneoplasia: thoughts on the nosology of the clonal myeloid diseases. Blood Cells Mol Dis 2000;26:572-81.

23. Weisdorf DJ, Oken MM, Johnson GJ. Chronic myelodysplastic syndrome: short survival with or without evolution to acute leukaemia. Br J Haematol 1983;55:691-700.

24. Porwit A. Diagnosis and WHO 2008 Classification of Myelodysplastic Syndromes. Available in URL: http://www.confacta.eu/images/ diagnosisandwhoclassificationofmdsap.pdf.

25. Mahmood MT . WHO 2008 classification of myeloid neoplasms what is new and why? [48 screens]. Available in URL:http://www. psh.org.pk/images/presentation/who 2008 classification of myeloid neoplasms-what is new dr.pdf

26. Odenike O, Le Beau MM. The Dawn of the Molecular Era of the Myelodysplastic Syndromes: Editorial. N Engl J Med 2011; 364:2545-6.

27. Bejar R, Stevenson K, Abdel-Wahab O et al. Clinical Effect of Point Mutations in Myelodysplastic Syndromes. N Engl J Med 2011;364: 2496-506.

28. Elghetany MT, Hudnall SD, Gardner FH. Peripheral blood picture in primary hypocellular refractory anemia and idiopathic acquired aplastic anemia: an additional tool for differential diagnosis. Haematologica. 1997;82:21-4.

29. Barrett J, Saunthararajah Y, Molldrem J. Myelodysplastic syndrome and aplastic anemia: distinct entities or diseases linked by a common pathophysiology? Semin Hematol. 2000;37:15-29.

30. Hasle H, Niemeyer CM, Chessells JM. A pediatric approach to the WHO classification of myelodysplastic and myeloproliferative diseases. Leukemia. 2003;17:277-82. 